\title{
The Influence of The Lecture's Example of Christian Education to The Development of The Student's Character
}

\author{
Feberman Sarumaha \\ Master Of Christian Education Program \\ St.Paul Theological School Of Medan \\ Medan, North Sumatera \\ Email : sttpaulus.oke@gmail.com
}

\author{
Heryanto \\ Lecture Of Doctoral Program Of Christian Leadership \\ St.Paul Theological School Of Medan \\ Medan, North Sumatera \\ Email : Dr.heryantodth@yahoo.co.id
}

\begin{abstract}
Responsibility of a lecturer does not only do teaching and complete all the tasks well, on the contrary, character building of a student gets less attention. Whereas the lecturer's example is an important part to develop student's character. Although the student needs molding to be not only a smart and superior person from cognitive side, but also affective side (Character) that will become a skilled man (Psychomotor). Based on the data analysis average, it gains score of the lecturer's example that is the highest 36,7 while student character is at 60,0 . The result of t-test analysis correlation of Product Moment shows the lecturer's example at the level of significance $5 \%$ with result 0,36 less than 0,463 . It is proven that the example of lecturers does not have any effects nor impacts on student character development
\end{abstract}

\section{Keywords : Transformative Learning And Educational Leadership}

\section{INTRODUCTION}

A lecturer is one of elements in the field of education that must play an active role and place his position as a professional in accordance with demands of a functional society [1]. Professionalism of a lecturer does not only give student some lessons, control the tasks and responsibilities of academic, but also be a leader who provides the transformation through teaching so that the students can develop a good character. Keep in mind that the most important element in character development is the mind because of the mind in which there is an entire program formed from the experience of his life, which is the pioneer of everything [2]. Therefore the existence of the lecturer is not only in groups (classical) but also individually. This requires the lecturer to pay attention and direct the attitudes, behavior, and actions of the students through example [3]. Accordingly, the imitable example indirectly affects the development of student characters. Educators as Opinion Leaders in educational institutions also have a central position in shaping the character or personality of the students. Example in an educator affects the surrounding environment and can give a large enough color to the community. Even it will change the behavior of people in its environment [4]. In terms of leadership, a Christian Education lecturer should also be able to direct, to guide and to influence students in Christian values to develop a good character but it often gets less attention so it is important to do a research in order to revise and to improve the example of lecturers together with the development of the student's character. So, the purpose of this research is important to know how the example of lecturer is needed and have a strong influence in building student character.

\section{THEORETICAL BASIS}

Generally, students' assessment for each lecturer tends to be good and positive, as well as the reality in the field found that lecturers have given a good example. The example of a lecturer relates to college's tri dharma that still needs some attentions and a quality improvement at Imanuel Nias Selatan Theological College. The main reason of it is to have a major influence in the formation of the student's character. A Christian Education lecturer should be a person who has a good spiritual experience through Biblical values. In performing duties as a lecturer must realize that Christian Education is a systematic and continuous effort of God and human beings to transmit knowledge, values, attitudes, skills and behavior consistent with the Christian faith. Education strives for a change, renewal and personal reformation, group and structure by the power of the Holy Spirit so that the students live according to the will of God, as the Bible and the Lord Jesus state [5]. The same thought is also said by Abdul Hakim Siregar, that the main purpose of education is to give birth to intelligent beings scholars, not only academically smart but also successful in building character in self-learners. Character is a way of thinking and behaving that is characteristic of each individual to live and work, both within the family, community, nation and state. Individuals who have good character is an individual who can make decisions and be ready to account for every result of the decisions he has made. Characters associated with the Almighty God, ourselves, our fellow human beings, the environment, and nationality embodied in thoughts, attitudes, feelings, words, and actions based on religious norms, laws, manners, culture, and customsy [6].

Thus, a Christian Education lecturer should be able to develop and transform the character of the students in the culture of life, skills and behavior in accordance with Christian values. All Christian values are built through the teaching and 
example of a lecturer because a lecturer is not only an educator but also a leader who can influence all of his students.

The main influence is through example both in communicating, teaching, personality and of course good spirituality. Syaiful Sagala says, "An effective leader delegate tasks as chances for growth and achievement, inspire, empower the subordinate, high involvement, and teams focusing activities on qualities services efficient costs and quantity output of production. There are six characteristic which distinguish a leader and non-leader, namely (a). spirit and ambition; (b) wish to lead and influence others; (c) honesty and integrity; (d) confidence; (e) smartness; and (f) mastery of technical knowledge related to the areas of his responsibility."[7].

Therefore, a lecturer should present an influence through the role of an influential leader who has intelligent qualification, integrity in faith, confidence, and mastery of knowledge so that he becomes an inspiration for the growth of the students' character and empowers the students to develop their character because when a student has a good character will be reflected in three things:

"A person of good character is moral knowing, moral feeling, and moral action. These three components would lead someone has a habit of thinking, habits of the heart, and the habit of acting, both addressed to the Almighty God, ourselves, others, the environment, and the nation"[8].

Based on some opinions above, it is concluded that the example of a lecturer of Religious Education must be seen and tested in a positive way for the students. To ensure the statements above then the researcher conducts this research with the formulation of the problem, they are:

a. Is the lecturer's example needed in the development of the student's character?

b. What is the reason of the students' character development requires the lecturer's example?

c. Has the lecturer's example already influenced on the students' character development well?

As a framework in this study built relationships between independent variables $(\mathrm{X})$ as the Lecturer's Example, while the Student's Character as dependent variable. The path diagram, as follows:

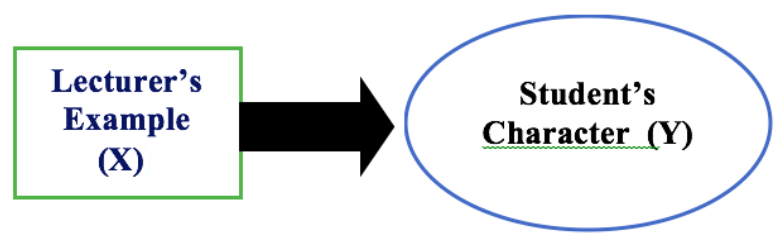

Fig. 1. Research scheme

\section{RESEARCH METHOD}

This research includes Explanatory, that is a research which explains the influence between independent variable with dependent variable and tests the hypothesis taught. [9] Furthermore, the research sample was taken by 30 people from the entire population as may as 110 people as said if the subject exceeds 100 people (large subject) can be taken 10$15 \%$ or $20-25 \%$ or more. [10] Then, the researcher used a closed questionnaire instrument type consists of 4 options namely a, b, c.d.

The researcher presented 25 items of questions that contain lecturer's example questions and 25 items about the character development. From each question consists of four alternative answers, they are a, b, c, d with value 4,3,2,1.

While to know the result or score obtained by summing the score and answer questionnaire score with the frequency of answers of each choice. For further explanation, the researcher presents about the lecturer's example (X) with the highest score is 94 and the lowest is 75 , while the student highest score is 92 and the lowest is 69 .

After the data is collected, it is done with the treatment to find the interval of influence of the lecturer's example $(\mathrm{X})$ on the student's character (Y) through the stages of analyzing the data. In this stage, the researcher uses two ways, they are the analysis of Data Assessment and Analysis Based on Score on variable X: Lecturer's example and variable Y: Student's character development.

\section{RESULT AND DISCUSSION}

\section{A. Lecturer Exemplary Data}

After obtaining the determination of interval result, analyzing the lecturer's example based on Data Score of Respondents Score, then the highest $\mathrm{X}$ variable score $=94$ and the lowest $=$ 75 then grouped the questionnaire based on Likert scale into 4 categories:

1) Rally Needed category: 90- 94 score

2) Needded category: 85 - 89 score

3) Occasionally category: 80 - 84 score

4) Unneeded category: 75 - 79 score

Furthermore, the result of the lecturer data analysis obtains in percentage, as follows:

TABLE 1. PERCENTAGE LEVEL OF LECTURE'S EXAMPLE

\begin{tabular}{|l|l|l|}
\hline \multicolumn{1}{|c|}{ Category } & $\begin{array}{c}\text { Sum of } \\
\text { Respondents }\end{array}$ & Percentage \\
\hline Really Needed & 11 & $36.7 \%$ \\
\hline Needed & 10 & $33,3 \%$ \\
\hline Occasionally & 5 & $16,7 \%$ \\
\hline Unneeded & 4 & $13.3 \%$ \\
\hline Total & 30 & $100 \%$ \\
\hline
\end{tabular}

From the analysis above, it seems that the example of the lecturer of Imanuel Theological College of South Nias through 30 respondents, the lecturer's example data is in the Really Needed category which reaches the highest percentage of $36.7 \%$, while the Needed category is $13.3 \%$. Therefore, the 
conclusion of the research results that the lecturer's example is really needed by students in the development of student's character.

\section{B. Student Character Development Data}

After obtaining the determination of interval outcome, the analysis of student character development data is done based on Respondents Score, then the highest score of 92 and the lowest is 69 then grouped the result of questionnaire based on Likert scale into four categories:

1) Most Important category: 87- 92

2) Important category: 81 - 86

3) Medium / Occasionally category: 75 - 80

4) Nonessential category: 69 - 74

Furthermore, the data analysis result of student character development, as follows:

TABLE 2. PERCENTAGE OF STUDENT'S CHARACTER DEVELOPMENT LEVEL

\begin{tabular}{|l|l|l|}
\hline \multicolumn{1}{|c|}{ Category } & $\begin{array}{c}\text { Sum of } \\
\text { Respondents }\end{array}$ & Percentage \\
\hline Most Important & 18 & $60 \%$ \\
\hline Important & 4 & $13,3 \%$ \\
\hline Medium & 5 & $16,7 \%$ \\
\hline Nonessential & 3 & $10 \%$ \\
\hline Total & 30 & $100 \%$ \\
\hline
\end{tabular}

From the analysis above, it seems that the student character character is influenced by the lecturer's example at Imanuel Theological College of South Nias through 30 respondents, the data of student character development in the Most Important category reaches the highest percentage that is $60 \%$ while the Important category is $10 \%$. Thus, the conclusion of this research that character development effort of a student is Most Important with the influence by the example of the lecturer.

\section{Product Moment Correlation Analysis}

Product Moment correlation analysis about the influence of the lecturer's example on the development of student's character at Imanuel Theological College in South Nias, then the researcher correlates the data that has been processed in the first and second analysis by using Product Moment correlation with deviation.

If $r$ is equal count or greater than $r$ table, then $r$ count is significant. In table $r$ Product Moment with $\mathrm{N}=30$, then can be selected in table score of Product Moment as follows:

The significant level of $5 \%=0.361$

So that it can be compared based on the score table obtained is:

$0.100<0.361$ at a significant level of $5 \%$ so, $r$ result is smaller than $r$ table Product Moment.

The result of statistical calculation above shows that the lecturer's example does not give influence to the development of the student's character when example is really needed and very important in giving influence to the student character development. According to the observation of the researcher that the factors as a strong reason for the lecturer's example does not affect the student, the lecturer may only prioritize the material income and limit the obligations or responsibilities, and even there is no emphasis from the management setting SOP in the institution. Therefore, this research has not been able to find the evidence of linkage between the lecturer's example and the student's character development. Considering the lack of perfect measurement instruments and the limited time and tools available in this study then this topic still needs to be reviewed in further research

\section{CONCLUSIONS AND SUGGESTION}

\section{A. Conclusion}

1) The lecturer's example at Imanuel Theologocal Seminary College in South Nias 2012/2013 that is at the highest category through 11 respondents generated percentage of $36.7 \%$ while the lowest category through 4 respondences generated percentage of $13.3 \%$, thus this study concludes that the level of requirement for the lecturer's example is really needed by student in the development of the student's character.

2) The development of the student's character in South Nias 2012/2013 that is the high category through 18 respondents obtain $60 \%$ percentage while the lowest category through 3 respondents obtain $10 \%$ percentage, thus this studi concludes that the development of student's character is very strongly influenced by the lecturer's example so that the examplary issue of the lecturer must be taken seriously by the lecturer.

3) After the data was analyzed by using product moment correlation formula so that the score $r_{x y}$ is 0,100 then at the level correlated with $\mathrm{r}$ table product moment with $\mathrm{n}-30$ at $5 \%$ significant tarif obtained 0,361 turns $r_{x y}$ score is less than $r$ table score. Thus it proves / it does not affect the lecturer's example with the development of the student's character at Imanuel Theological College of South Nias.

\section{b. Suggestions}

First, the advice is addressed to the lecturers of Christian Education. The role of a lecturer does not merely teach the class material but can live the teaching through the lecturer's example at the center of the students and the college environment. It is very important for the lecturers of Christian Education reflects on the example of the Lord Jesus in His life and ministry, this is what should be taught to all students. Because a teacher or a lecturer should realize himself like a mirror that is clearly visible of all attitudes and behavior for all students, therefore give the students the best example to be imitated by them.

Secondly, the advice is addressed to all students, especially Christian Education students. A success is not merely depend on cognitive / knowledge alone but you can have good 
affective / behavior in psychomotor / good life experience as well. Therefore, a student must be a creative person looking for positive values and self-building. The ultimate example is from the Lord Jesus and the lecturers who have positive values.

\section{REFERENCES}

[1] Sardiman, A.M. Interaksi Dan Motivasi Belajar Mengajar, Jakarta : Raja Grafindo Persada, 2000,

[2] Byne, Rhonda, The Secret, Jakarta : PT. Gramedia, 2007.

[3] Djamarah, Bahri Syaiful, Guru Dan Anak Didik Dalam Interaksi Edukatif Jakarta : Rineka Cipta, 2000.

[4] http://www,scribd.com/doc/33044252/Urgensi-Keteladanan-GuruDalam-Membentuk-Karakter-Anak-Bangsa, Diakses September 2017

[5] Pazmino, W., Robert, Foundation Issues In Christian Education, Grand Rapids Michigan : Baker,1988.

[6] Siregar, Hakim Abdul, Proceeding of the First Annual International Seminar on Transformative Education and Educational Leadership Vol.I, "Character Education For Youths Through Scoting Activity In Antipating Globalization, e-ISSN 2548-4613 Medan : UnimedAISTEEL, 2016, pp.73

[7] Sagala, Sayful Proceeding of the First Annual International Seminar on Transformative Education and Educational Leadership Vol.I, "Headmaster's Transformative Leadership Resulting In Quality Performance, e-ISSN 2548-4613, Medan : Unimed,-AISTEEL 2016, pp.762

[8] Sinambela, P.N.J.M, Siagian, Sahat, and Hutapea, T.A., Proceeding of the First Annual International Seminar on Transformative Education and Educational Leadership Vol.I, "Development Character Education Model In Unimed Based Six Characters For Enhancing Creativity Student Activity, e-ISSN 2548-4613, Medan : Unimed,-AISTEEL 2016, pp.172

[9] Sugiyono, Statistik Untuk Penelitian, Bandung : Alfabeta, 2008.

[10] Maxwell, Clerk James, A Treatise on Electricity and Magnetism, 3rd ed., vol. 2. Oxford: Clarendon, 1892.

[11] Suharsini, Arikunto, Prosedur Penelitian, Jakarta : Rineka Cipta, 2006. 